\title{
Synthesis and structural characterization of $\left(\mathrm{Bi}_{2} \mathrm{O}_{3}\right)_{1-x}\left(\mathrm{Y}_{2} \mathrm{O}_{3}\right)_{x}$ and $\left(\mathrm{Bi}_{2} \mathrm{O}_{3}\right)_{1-x}\left(\mathrm{Gd}_{2} \mathrm{O}_{3}\right)_{x}$ solid solutions
}

\author{
SRIKANT EKHELIKAR and G K BICHILE* \\ Department of Physics, Dr Babasaheb Ambedkar Marathwada University, Aurangabad 431 004, India
}

MS received 1 August 2003; revised 10 December 2003

\begin{abstract}
Solid solution series, $\left(\mathrm{Bi}_{2} \mathrm{O}_{3}\right)_{1-x}\left(\mathrm{Y}_{2} \mathrm{O}_{3}\right)_{x}$ and $\left(\mathrm{Bi}_{2} \mathrm{O}_{3}\right)_{1-x}\left(\mathrm{Gd}_{2} \mathrm{O}_{3}\right)_{x}$, for $x=0 \cdot 10,0 \cdot 20,0 \cdot 30$ and $0 \cdot 40$ were synthesized by standard ceramic technique. The structural phase characterization was carried out using $\mathrm{X}$-ray powder diffraction technique. It was found that the solid solution containing 20-40 mole\% of $\mathrm{Y}_{2} \mathrm{O}_{3}$ had face-centred cubic structure. All samples of the solid solution series, $\left(\mathrm{Bi}_{2} \mathrm{O}_{3}\right)_{1-x}\left(\mathrm{Gd}_{2} \mathrm{O}_{3}\right)_{x}$, had rhombohedral single phase in the concentration range $0 \cdot 10 \leq x \leq 0 \cdot 40$. Lattice parameters of $f c c$ phase of $\mathrm{Y}_{2} \mathrm{O}_{3}$ doped samples were calculated from the $\mathrm{X}$-ray diffraction data. The lattice constant ' $a$ ' gradually decreases with increasing content of dopant concentration $(x)$ for the $\mathrm{Y}_{2} \mathrm{O}_{3}$ doped system and obeys Vegard's rule. The unit cell parameters for the $\left(\mathrm{Bi}_{2} \mathrm{O}_{3}\right)_{1-x}\left(\mathrm{Gd}_{2} \mathrm{O}_{3}\right)_{x}$ doped samples showing rhombohedral phase were obtained on hexagonal setting.
\end{abstract}

Keywords. Fast ion conductors; fluorite structure; fuel cell materials.

\section{Introduction}

Fast ion conductors have been a subject of extensive research because of their interesting physical properties as well as their potential technological use (Takahashi et al 1992). High ionic mobility in a crystalline solid is a primary requirement and it can only be achieved in the presence of disorder (Hagenmuller 1978). The materials with fluorite structure can be disordered either by thermal activation (intrinsic conductors) or by doping with trivalent ions (extrinsic conductors) such as lanthanides. These systems are therefore, excellent candidates for studies of mechanism of ion transport in crystalline materials. In recent years, the fluorite structured solid solutions have been the subject of numerous experimental studies focused on their fast ion conducting behaviour (Kilner 2000). An interesting subgroup of this class of materials are the oxides that display oxygen ion conductivity. There has been a continued drive towards the synthesis of new materials and their development because of the promise of important technological devices such as solid oxide fuel cells (SOFC), oxygen separation membrane etc (Harwig and Gerads 1978; Kilner 1997). All these devices offer the potential of enormous commercial and ecological benefits provided suitable high performance material can be developed.

Among the various types of oxygen ion conductors (Sethi and Gauer 1955), the anion deficient fluorite structured oxides such as calcia-stabilized zirconia and $\delta$ -

*Author for correspondence
$\mathrm{Bi}_{2} \mathrm{O}_{3}$ oxides are still the best known oxygen ion conductors. Moreover, the simplicity of the structure and bonding in fluorites makes them ideal systems for fundamental, theoretical and experimental studies. Bismuth oxide $(\delta$ phase) is known to have a defect fluorite type structure including large amounts of vacant sites in the oxide ion sublattice (Sethi and Gauer 1955). These materials show high oxide ion conductivity under ordinary atmosphere (Dutta and Mechan 1971). This phase, is, however, stable only in the narrow temperature range of $730-825^{\circ} \mathrm{C}$. The conductivity falls remarkably below $730^{\circ} \mathrm{C}$ and the substance undergoes a phase transition to monoclinic structured $\alpha$-phase. It is, therefore, interesting to stabilize the high conducting $\delta$-phase at low temperatures by doping bismuth oxide with alio or iso valent ions with the aim of stabilizing the $f c c$ phase at low temperature. Although the phase diagrams of $\mathrm{Bi}_{2} \mathrm{O}_{3}-\mathrm{M}_{2} \mathrm{O}_{3}$ are partly studied (Turkoglu et al 2002), the composition range studied are rather narrow and are limited to the $\mathrm{Bi}_{2} \mathrm{O}_{3}$ rich region ( $\geq 90$ mole\% of $\mathrm{Bi}_{2} \mathrm{O}_{3}$ ). In the present paper we report investigations that have been carried out on the synthesis and structural characterization of $\left(\mathrm{Bi}_{2} \mathrm{O}_{3}\right)_{1-x}\left(\mathrm{Y}_{2} \mathrm{O}_{3}\right)_{x}$ and $\left(\mathrm{Bi}_{2} \mathrm{O}_{3}\right)_{1-x}\left(\mathrm{Gd}_{2} \mathrm{O}_{3}\right)_{x}$ systems. The exact range of dopant concentrations that stabilizes the fluorite phase has been identified. The results on other bismuth oxide based systems are reported elsewhere.

\section{Experimental}

Two series of samples having the composition, $\left(\mathrm{Bi}_{2} \mathrm{O}_{3}\right)_{1-x}$ $\left(\mathrm{Y}_{2} \mathrm{O}_{3}\right)_{x}$ and $\left(\mathrm{Bi}_{2} \mathrm{O}_{3}\right)_{1-x}\left(\mathrm{Gd}_{2} \mathrm{O}_{3}\right)_{x}$, for $x=0 \cdot 10,0 \cdot 20,0 \cdot 30$ 
and 0.40 were prepared by using standard solid state reaction technique. Appropriate quantities of the required constituent oxides of high purity $(99.99 \%)$ fine powders of $\mathrm{Bi}_{2} \mathrm{O}_{3}$ (Thomas Baker), $\mathrm{Y}_{2} \mathrm{O}_{3}$ and $\mathrm{Gd}_{2} \mathrm{O}_{3}$ (E Merck) were thoroughly dry mixed and ground using agate mortar and pestle. This mixture was heated in air at $725^{\circ} \mathrm{C}$ for $12 \mathrm{~h}$ in platinum crucibles to obtain homogeneous product. The material thus obtained after first heating was reground till a fine powder was obtained and it was again kept for second heating at $825^{\circ} \mathrm{C}$ for $12 \mathrm{~h}$ and slowly cooled at $5^{\circ} \mathrm{C}$ per min until room temperature was reached. The product thus obtained after second heating was then finally ground and cold pressed into pellets that were sintered in air from $800^{\circ}-1000^{\circ} \mathrm{C}$. It was observed

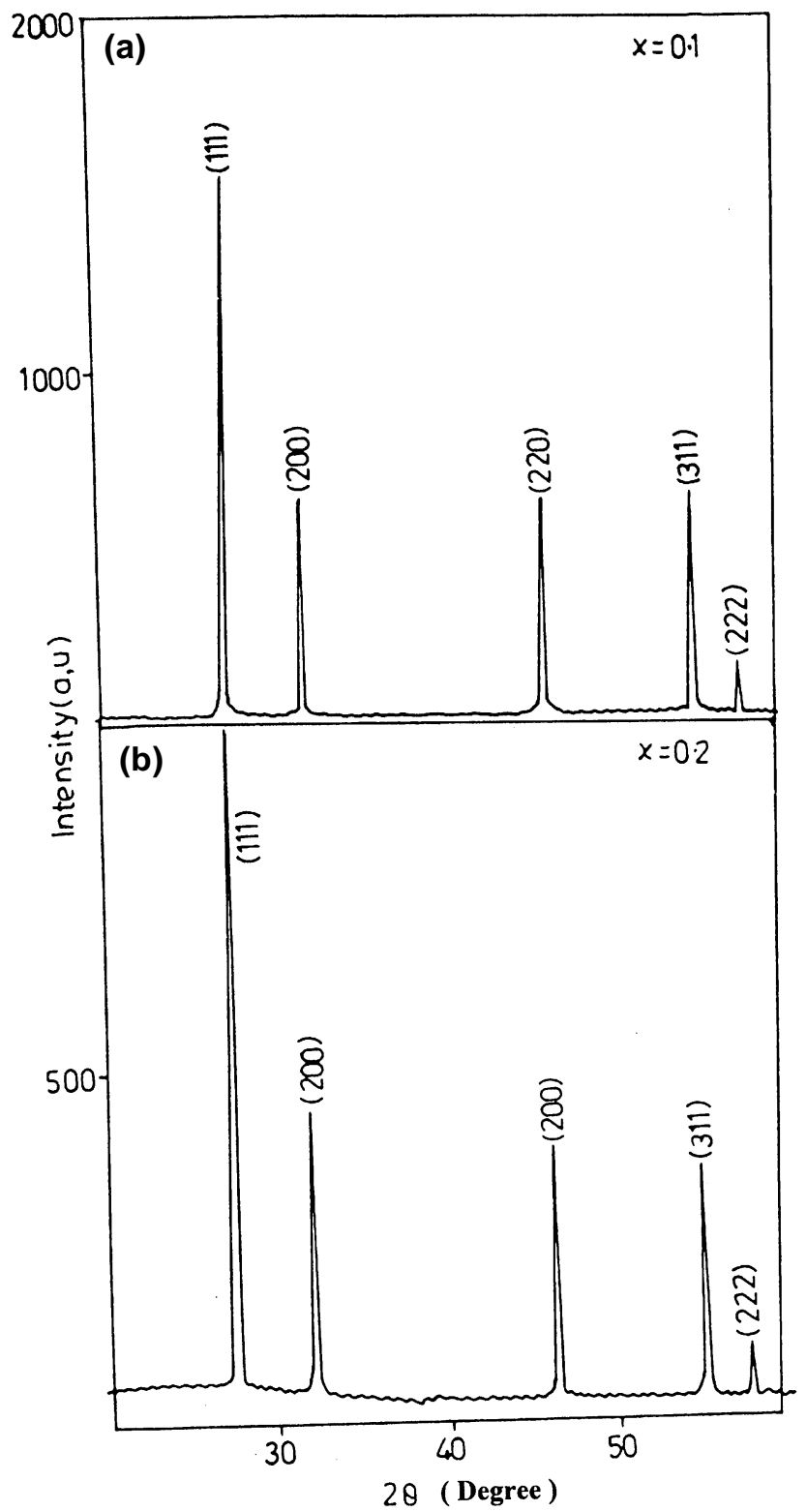

that greater the content of doped oxide the higher was the sintering temperature. All these samples were prepared in carbolite furnace using Eurotherm temperature controller.

All the samples were characterized at room temperature by $\mathrm{X}$-ray diffraction using $\mathrm{CuK}_{\alpha}$ radiation. The XRD data were analysed to index the Bragg peaks and to identify the phases present. Unit cell parameters were evaluated from the positions of Bragg peaks.

\section{Results and discussion}

$\left(\mathrm{Bi}_{2} \mathrm{O}_{3}\right)_{1-x}\left(\mathrm{Y}_{2} \mathrm{O}_{3}\right)_{x}$ system: All the samples were characterized at room temperature by $\mathrm{X}$-ray diffraction using

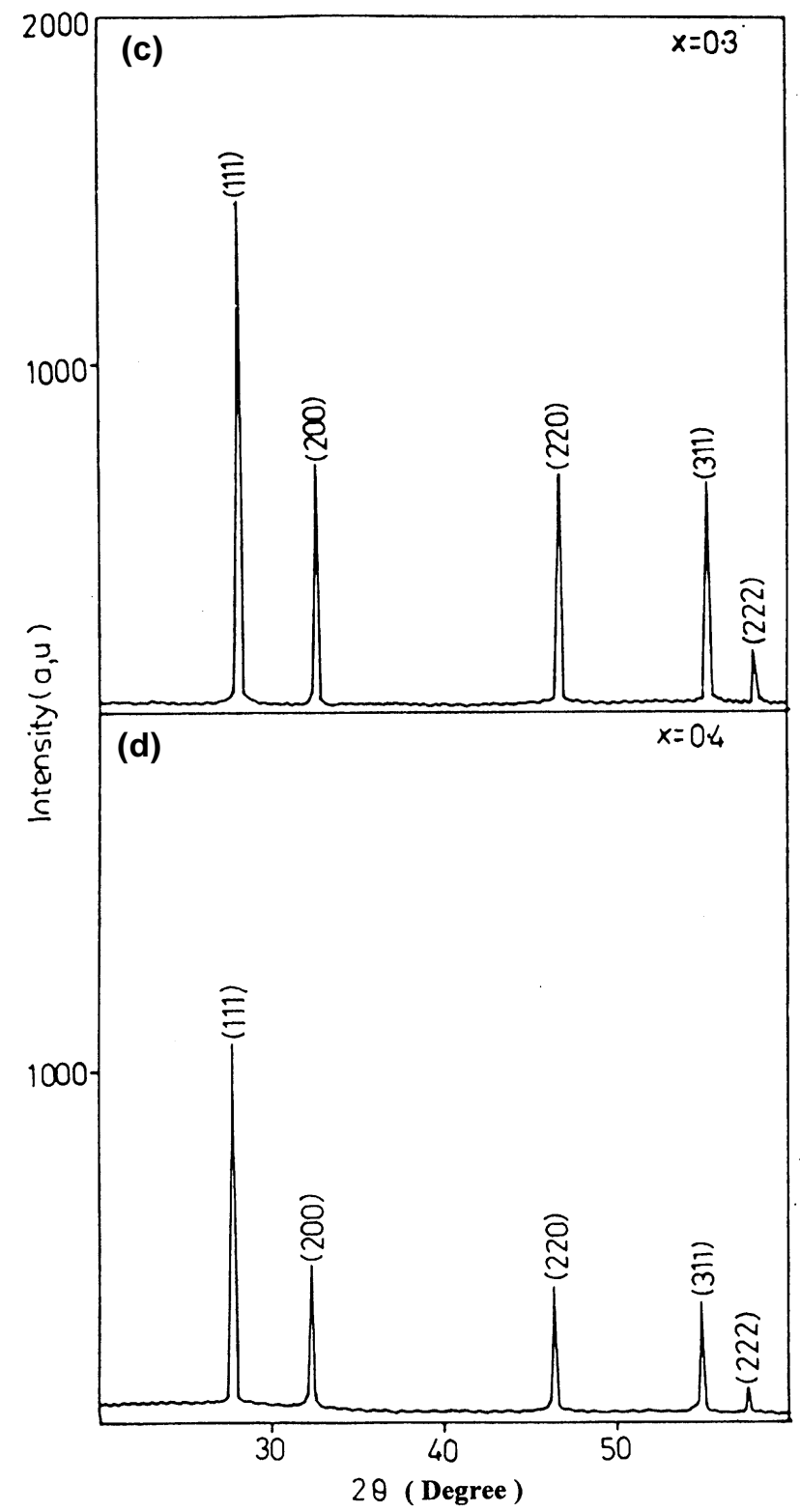

Figure 1. X-ray diffraction patterns of $\left(\mathrm{Bi}_{2} \mathrm{O}_{3}\right)_{1-x}\left(\mathrm{Y}_{2} \mathrm{O}_{3}\right)_{x}$ for $\mathbf{a} . x=0 \cdot 10$, b. $x=0 \cdot 20$, c. $x=0 \cdot 30$ and d. $x=0 \cdot 40$. 


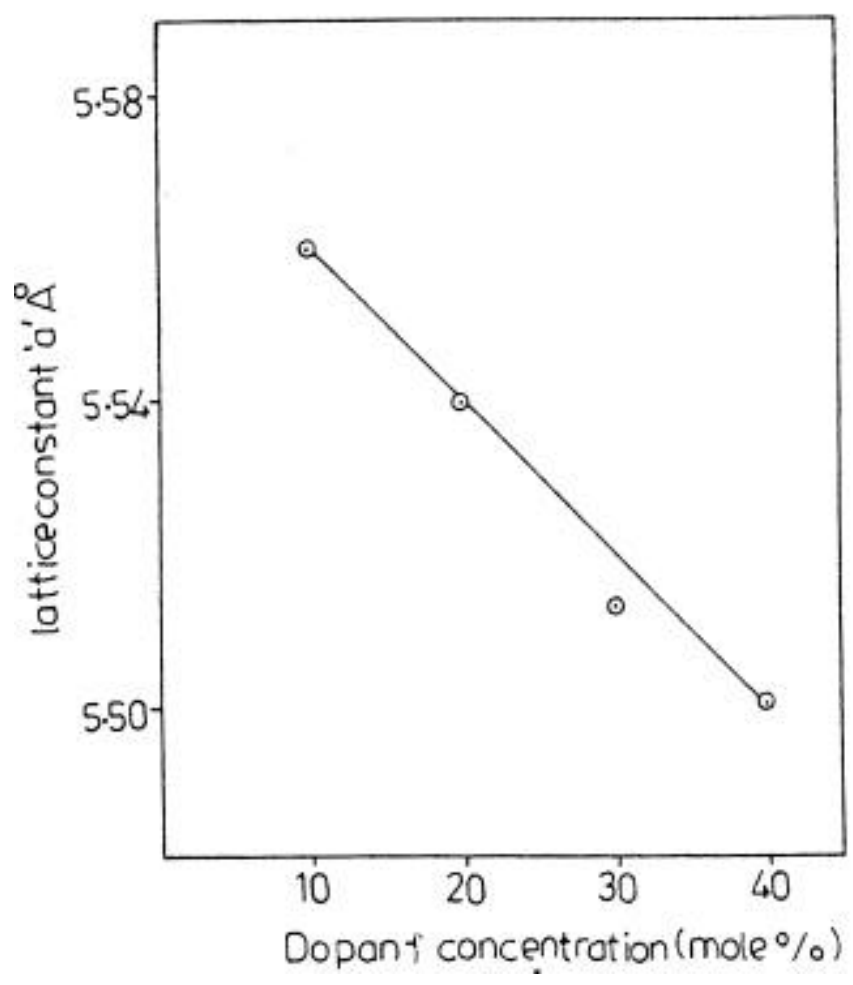

Figure 2. Variation of lattice parameter with dopant concentration for $\left(\mathrm{Bi}_{2} \mathrm{O}_{3}\right)_{1-x}\left(\mathrm{Y}_{2} \mathrm{O}_{3}\right)_{x}$.

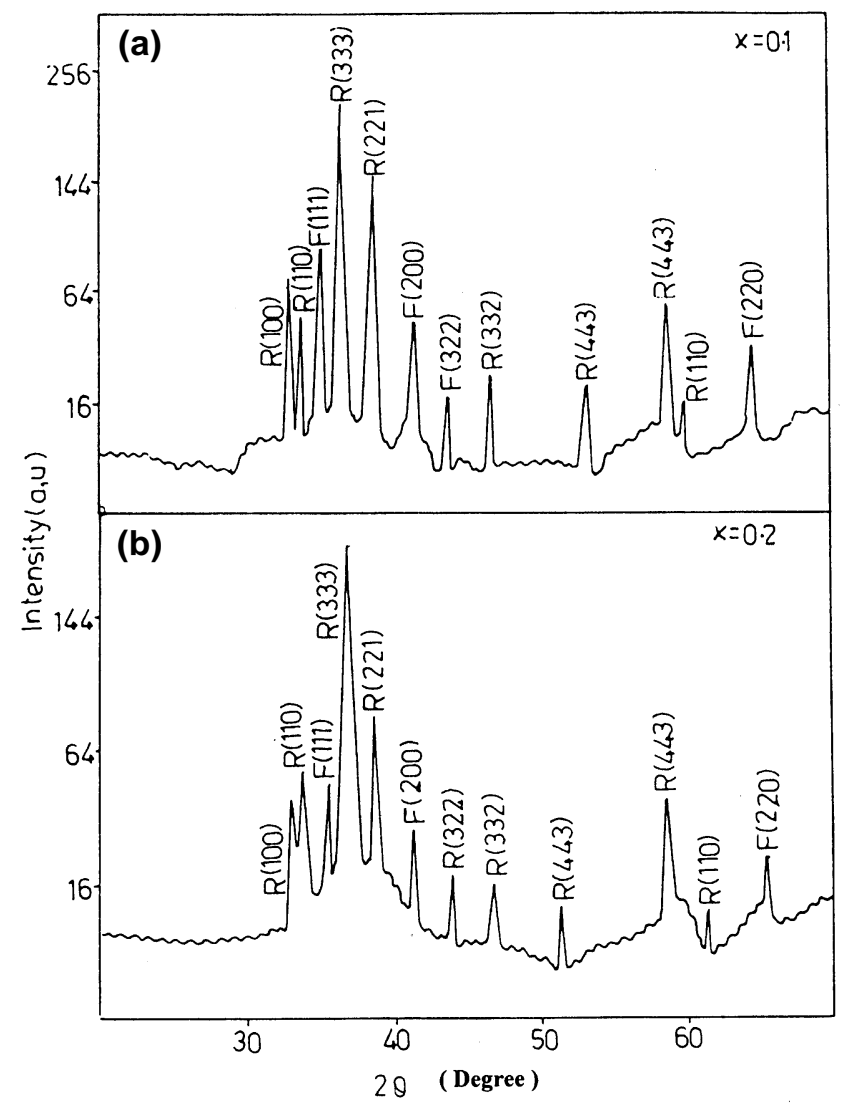

$\mathrm{CuK}_{\alpha}$ radiation. The $\mathrm{X}$-ray analysis revealed that all samples were single phase as seen from the absence of extra peaks. The X-ray peaks were indexed and lattice parameters were evaluated using REFIDET least square programme. The observed X-ray diffraction patterns of all the samples of this series are shown in figures $1 \mathrm{a}-\mathrm{d}$. The lattice parameter and structural phases present are tabulated in table 1 . It is observed that the values of lattice parameter ' $a$ ' decreases with increasing dopant concentration as shown in figure 2 and obeys Vegard's rule in the composition range $10-40 \mathrm{~mole} \%$. This implies that the system, $\left(\mathrm{Bi}_{2} \mathrm{O}_{3}\right)_{1-x}\left(\mathrm{Y}_{2} \mathrm{O}_{3}\right)_{x}$, forms a solid solution series over a wide range of compositions. Specimens containing $<10$ mole $\%$ of $\mathrm{Y}_{2} \mathrm{O}_{3}$ showed mixed phases.

$\left(\mathrm{Bi}_{2} \mathrm{O}_{3}\right)_{1-x}\left(\mathrm{Gd}_{2} \mathrm{O}_{3}\right)_{x}$ system: X-ray diffraction patterns of $\mathrm{Gd}_{2} \mathrm{O}_{3}$ doped samples are displayed in figures $3 \mathrm{a}-\mathrm{d}$. A series of compounds having the composition, $\left(\mathrm{Bi}_{2} \mathrm{O}_{3}\right)_{1-x}$ $\left(\mathrm{Gd}_{2} \mathrm{O}_{3}\right)_{x}$, for $x=0 \cdot 10,0 \cdot 20,0.30$ and 0.40 were characterized by X-ray diffraction using PW 1700 (Philips make, Holland) X-ray diffractometer using Fe target. The observed XRD patterns were analysed and the refined unit cell parameters were calculated using the standard least square refinement programme. All the four $\mathrm{Gd}_{2} \mathrm{O}_{3}$ doped samples exhibited rhombohedral structure. The values of the unit cell parameters were obtained on hexa-

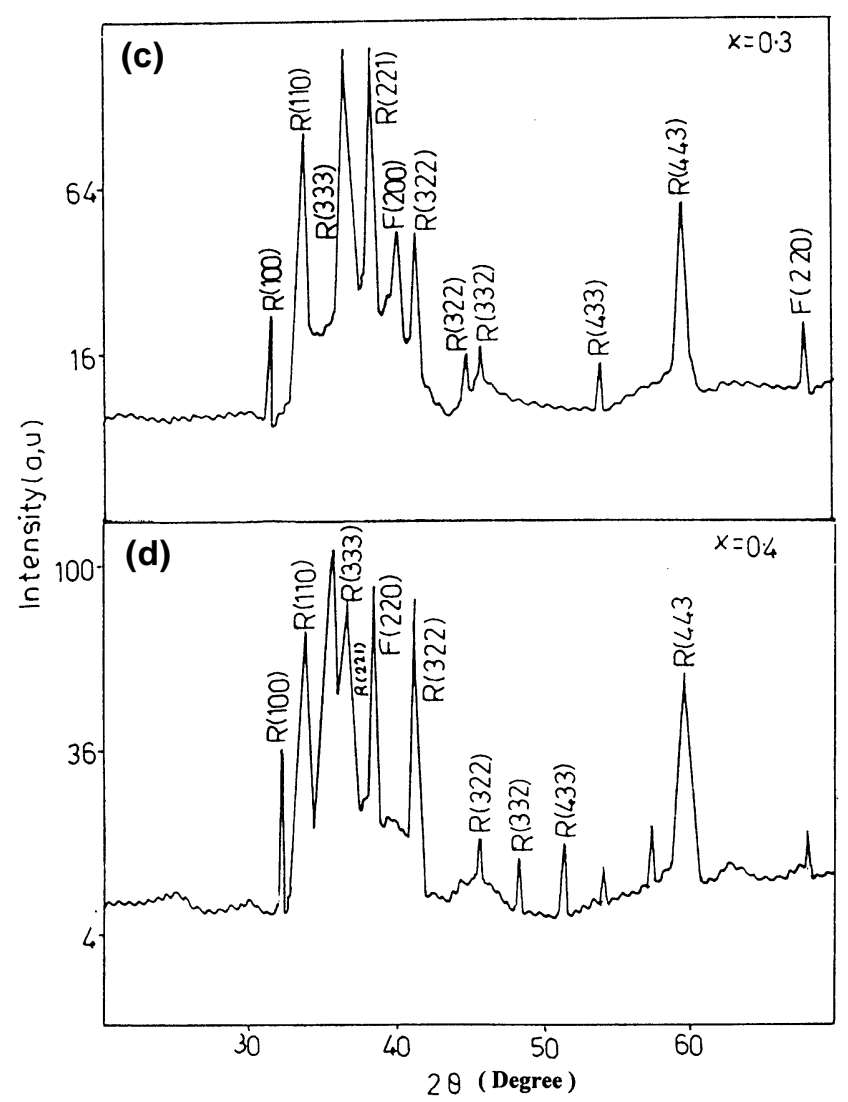

Figure 3. X-ray diffraction patterns of $\left(\mathrm{Bi}_{2} \mathrm{O}_{3}\right)_{1-x}\left(\mathrm{Gd}_{2} \mathrm{O}_{3}\right)_{x}$ for a. $x=0 \cdot 10$, b. $x=0 \cdot 20$, c. $x=0 \cdot 30$ and d. $x=0 \cdot 40$. 
Table 1. Unit cell parameter, unit cell volume and structural phases present in $\left(\mathrm{Bi}_{2} \mathrm{O}_{3}\right)_{1-x}\left(\mathrm{Y}_{2} \mathrm{O}_{3}\right)_{x}$.

\begin{tabular}{lccc}
\hline $\begin{array}{l}\text { Composition, } \\
X(\text { mole } \%)\end{array}$ & $\begin{array}{c}\text { Unit cell } \\
\text { parameter, } a(\AA)\end{array}$ & $\begin{array}{c}\text { Unit cell } \\
\text { volume, } \\
V=a^{3}(\AA)\end{array}$ & $\begin{array}{c}\text { Structural } \\
\text { phase present }\end{array}$ \\
\hline 10 & $5 \cdot 560 \pm 0 \cdot 002$ & $171 \cdot 88$ & $f c c$ \\
20 & $5 \cdot 540 \pm 0.002$ & 170.03 & $f c c$ \\
30 & $5 \cdot 520 \pm 0.002$ & $168 \cdot 20$ & $f c c$ \\
40 & $5 \cdot 500 \pm 0.002$ & $166 \cdot 38$ & $f c c$ \\
\hline
\end{tabular}

Table 2. Unit cell parameter, unit cell volume and structural phase present in $\left(\mathrm{Bi}_{2} \mathrm{O}_{3}\right)_{1-x}\left(\mathrm{Gd}_{2} \mathrm{O}_{3}\right)_{x}$.

\begin{tabular}{lcccl}
\hline \multirow{2}{*}{$\begin{array}{l}\text { Composition, } \\
X(\text { mole } \%)\end{array}$} & \multicolumn{2}{l}{ On rhombohedral lattice } & \\
\cline { 2 - 4 } & $a_{\mathrm{R}}(\AA)$ & $\alpha^{\circ}$ & $V_{\mathrm{R}}(\AA)^{3}$ & Structural phase \\
\hline 10 & $9 \cdot 506$ & $24 \cdot 09$ & $120 \cdot 00$ & Rhombohedral \\
20 & $9 \cdot 505$ & $24 \cdot 18$ & $125 \cdot 30$ & Rhombohedral \\
30 & $9 \cdot 508$ & $24 \cdot 25$ & $121 \cdot 19$ & Rhombohedral \\
40 & $9 \cdot 481$ & 24.33 & $123 \cdot 50$ & $\begin{array}{l}\text { Rhombohedral }+ \\
\text { impurity peaks }\end{array}$ \\
\hline
\end{tabular}

gonal setting and tabulated in table 2 . The results of present study reveal that the $f c c$ phase is not stabilized in $\mathrm{Gd}_{2} \mathrm{O}_{3}$ doped samples within the range of dopant concentrations studied.

From the consideration of the cationic radius of the dopant oxides, it is expected that the oxide ion conductive phase in the system, $\left(\mathrm{Bi}_{2} \mathrm{O}_{3}\right)_{1-x}\left(\mathrm{M}_{2} \mathrm{O}_{3}\right)_{x}$, is rhombohedral in the case of a relatively large ionic radius of $\mathrm{M}^{3+}$ and is $f c c$ in the case of comparatively small ionic radius of $\mathrm{M}^{3+}$. The rhombohedral phase is formed in the system doped with $\mathrm{Gd}_{2} \mathrm{O}_{3}$, the cationic radius of $\mathrm{Gd}^{3+}(0.94 \AA)$ ions are comparatively large. The $f c c$ phase is stabilized by doping with oxides with relatively small cationic radius $\mathrm{Y}^{3+}(0.90 \AA)$ than $\mathrm{Bi}^{3+}(1.03 \AA)$. The deviation in structural stabilization is due to the difference in electronic configuration of $\mathrm{Y}(5 d)$ and $\mathrm{Gd}(5 f)$.

\section{Conclusions}

From the results of the present study it is observed that fluorite structured $f c c$ phase is retained for the dopant concentration $(x)$ lying between 10 mole \% and 40 mole $\%$ for $\mathrm{Y}_{2} \mathrm{O}_{3}$ doped systems. The rhombohedral phase is observed for $\mathrm{Gd}_{2} \mathrm{O}_{3}$ doped system for the dopant concentrations lying between 10 mole $\%$ and 40 mole\% of $\mathrm{Gd}_{2} \mathrm{O}_{3}$.

\section{References}

Dutta R K and Mechan J P 1971 Allg. Chem. 38328

Hagenmuller P 1978 Solid electrolytes (New York: Academic Press)

Harwig H A and Gerads A G 1978 J. Solid State Chem. 26265

Kilner J A 1997 Chem. \& Ind. 22907

Kilner J A 2000 Solid State Ionics 12913

Sethi R S and Gauer H G 1955 Indian J. Chem. 3177

Takahashi T, Iwahara H and Nagai Y 1992 J. Appl. Electrochem. 297

Turkoglu O, Soylak M and Belenli I 2002 Bull. Mater. Sci. 25 583 